\author{
Ashok Raj R \\ Pavendhan $R$ \\ Kumaragurubaran $B$
}

https://doi.org/10.21278/TOF.44208

ISSN 1333-1124

eISSN 1849-1391

\title{
INVESTIGATION INTO TRIBOLOGICAL BEHAVIOUR OF AL7075 AND AL7075 HYBRID COMPOSITES
}

\begin{abstract}
Summary
The aluminium metal matrix composite (AMMC) is widely used in aerospace and automotive applications. The AMMC reinforced with titanium diboride $\left(\mathrm{TiB}_{2}\right)$, exhibits excellent tribological properties. In this study, molybdenum disulfide $\left(\mathrm{MoS}_{2}\right)$ was used as a reinforcement to improve the tribological properties of the $\mathrm{Al}^{7} 7075-\mathrm{TiB}_{2}$ composite. The Al7075 hybrid composites were produced with $12 \mathrm{wt} \%$ of $\mathrm{TiB}_{2}$ with varied mass loading of $\mathrm{MoS}_{2}(\mathrm{x}=0,1.5,3,4.5)$ by using the powder metallurgy method. The energy dispersive Xray spectroscopy (EDX) test confirmed the presence of reinforcements. The Al7075 composites were examined for the study of microstructure, microhardness and tribological behaviour by using a scanning electron microscope (SEM), Vickers microhardness tester and pin-on-disc equipment, respectively. The tribological properties of A17075 hybrid composites are superior to those of aluminium alloy A17075. The low wear loss $(10 \mathrm{mg})$ and coefficient of friction (0.109) were produced at the sliding velocity of $2 \mathrm{~m} / \mathrm{s}$, the sliding distance of $1000 \mathrm{~m}$ and the applied load of $5 \mathrm{~N}$ in the $\mathrm{Al} 7075-12 \% \mathrm{TiB}_{2}-4.5 \% \mathrm{MoS}_{2}$ composite.
\end{abstract}

Key words: $\quad$ microstructure, microhardness, wear loss, coefficient of friction, reinforcements

\section{Introduction}

Composites are lightweight materials with excellent performance that can change the usage of conventional materials in different kinds of advanced applications, such as automotive, marine and aerospace applications [1-3]. The properties of composites are customized by changing the fraction, size and sort of reinforcing particles [4, 5]. Among the different composite manufacturing processes, powder metallurgy is one of the most important processes and incorporates the blending of powders, compacting, and sintering [6-8]. Aluminium alloy $\mathrm{Al} 7075(\mathrm{Al}-\mathrm{Zn}-\mathrm{Mg}-\mathrm{Cu})$ is one of the hardest aluminium alloys in industrial use today because of its excellent strength-to-weight ratio and natural aging characteristics [6-10]. Ultrafine grain tungsten was prepared with the help of a ball milling method. It is employed to synthesize a variety of alloy materials with stable and metastable phases. $\mathrm{TiB}_{2}$ exhibits a high melting point and higher hardness when compared to other ceramics. $\mathrm{TiB}_{2}$ is thermally and electrically conductive. Ding et al. presented the spark plasma sintering of $\mathrm{W}-1 \% \mathrm{TiC}$ which produces an average grain size of $3 \mu \mathrm{m}$ and a relative density of $98.6 \%[11,12]$. Ravichandran and 
Anandakrishnan optimized the powder metallurgy process parameters to achieve maximum strength of Al-based composites [13]. The matrix has a homogeneous dispersion of reinforcement particles [14]. The mechanical properties are strongly influenced by the $\mathrm{TiB}_{2}$ particle size in the $\mathrm{TiB}_{2}$ reinforced MMC [15]. A recent study indicates that mixing a small amount of graphite produces excellent tribological properties that are superior to those of base alloys. The literature review reveals that the introduction of graphite $(\mathrm{Gr})$ as a solid lubricant is not an appropriate reinforcement for functioning under the vacuum atmosphere [16]. The conversion of a transcendent wear mechanism from adhesion to abrasion occurred when $\mathrm{MoS}_{2}$ particles were incorporated in pure aluminium [17]. Based on the literature review, an investigation was made to fabricate the $\mathrm{TiB}_{2}$ and $\mathrm{MoS}_{2}$ reinforced aluminium 7075 hybrid composite by using ball milling and powder metallurgy and to study the effect of reinforcement by conducting microhardness and wear tests on the A17075 hybrid composite.

\section{Experimental setup and procedure}

\subsection{Materials}

Al7075 was chosen as matrix material with an average particle size of $2 \mu \mathrm{m}$. $\mathrm{TiB}_{2}$ and $\mathrm{MoS}_{2}$ were chosen as hard reinforcement and soft reinforcement with an average particle size of $10 \mu \mathrm{m}$ and $2 \mu \mathrm{m}$, respectively. The average particle size of the matrix powder and the reinforcement powder is identified with the help of a particle size analyser (PSA). The density of $\mathrm{TiB}_{2}$ and $\mathrm{MoS}_{2}$ powders is $4.52 \mathrm{~g} / \mathrm{cm}^{3}$ and $5.06 \mathrm{~g} / \mathrm{cm}^{3}$, respectively. The chemical composition of Al7075 is shown in Table 1.

Table 1 Composition of AL7075

\begin{tabular}{cccccccccc}
\hline Element & $\mathbf{Z n}$ & $\mathbf{C u}$ & $\mathbf{M n}$ & $\mathbf{M g}$ & $\mathbf{F e}$ & $\mathbf{C r}$ & $\mathbf{S i}$ & $\mathbf{T i}$ & $\mathbf{A l}$ \\
\hline $\mathbf{W t} \%$ & 5.6 & 1.5 & 0.06 & 2.4 & 0.24 & 0.20 & 0.08 & 0.07 & Rem. \\
\hline
\end{tabular}

\subsection{Fabrication of the composite}

The powder metallurgy technique was used to produce the A17075 hybrid composite. A17075 powder was taken as matrix material because it has excellent strength and corrosionresistance. To conduct the investigation, 16 specimens were fabricated for each type of sample.

$$
\begin{aligned}
& \text { Sample A - Unreinforced Al7075 } \\
& \text { Sample B - Al7075-12\% } \mathrm{TiB}_{2} \\
& \text { Sample C - Al7075-12\% } \mathrm{TiB}_{2}-1.5 \% \mathrm{MoS}_{2} \\
& \text { Sample D - Al7075-12\% } \mathrm{TiB}_{2}-3 \% \mathrm{MoS}_{2} \\
& \text { Sample E - Al7075-12\% } \mathrm{TiB}_{2}-4.5 \% \mathrm{MoS}_{2}
\end{aligned}
$$

The scanning electron microscope (SEM) images of $\mathrm{Al7075}, \mathrm{TiB}_{2}$ and $\mathrm{MoS}_{2}$ powder particles are shown in Figs. 1-3, respectively. A17075 alloy powder was purchased from M/s Metal Powders Company limited, Madurai, Tamil Nadu, India. $\mathrm{TiB}_{2}$ and $\mathrm{MoS}_{2}$ were acquired from Sigma Aldrich with the help of Subra Company, Bangalore, India. Al7075, $\mathrm{TiB}_{2}$ and $\mathrm{MoS}_{2}$ powders were mixed in a planetary tumbler mixer with the help of stainless steel balls of $8 \mathrm{~mm}$ in diameter and mixed in a weight ratio of 10:1 (ball to powder). In the tumbler mixer, toluene ( $2 \%$ by weight) was used to prevent the sticking of the powders to balls. The powders were mixed for a time interval of 30 minutes at a speed of $250 \mathrm{rpm}$. The Al7075 matrix powders were mixed with $12 \% \mathrm{TiB}_{2}$ and $\mathrm{MoS}_{2}(\mathrm{X}=0,1.5 \%, 3 \%, 4.5 \%)$ reinforcements in the tumbler mixer. The mixed powders were compacted at $800 \mathrm{MPa}$ in a uniaxial hydraulic press. Zinc stearate was applied on the wall of the die to prevent the sticking of powders. The sintering 
was done on green compacts at $590^{\circ} \mathrm{C}$ for 90 minutes to increase the composite strength. The sintered composites were further cooled in the atmospheric air. The hybrid composite specimen size is maintained at a height of $30 \mathrm{~mm}$ and a diameter of $10 \mathrm{~mm}$.

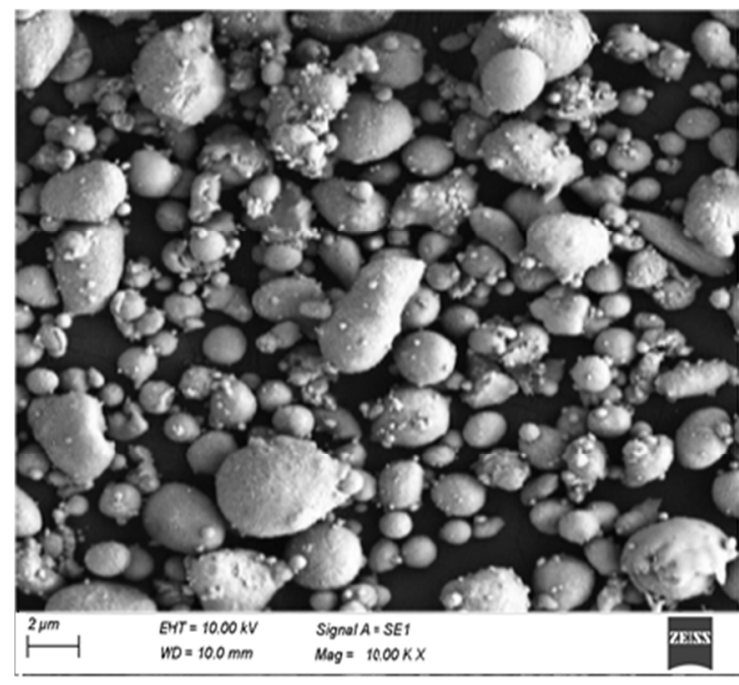

Fig. 1 Al7075 powders

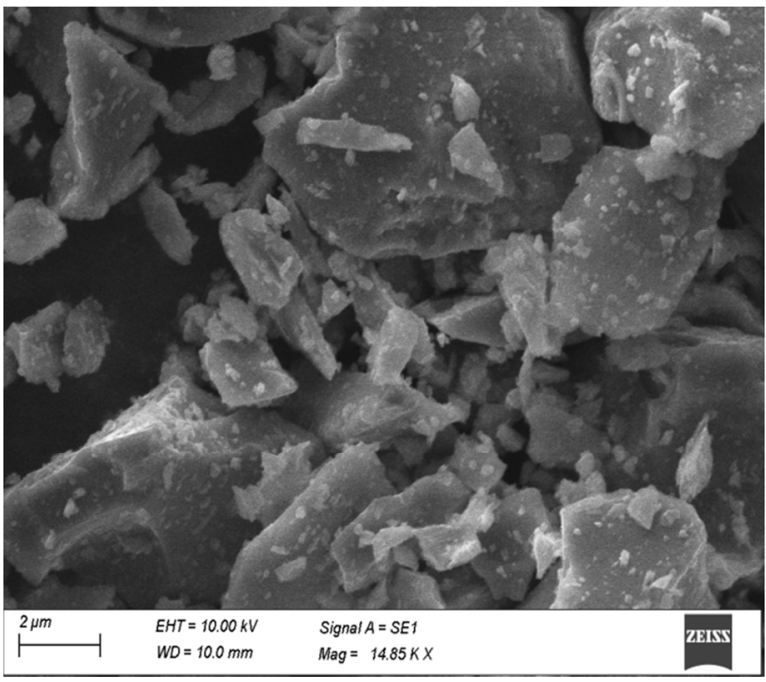

Fig. $2 \mathrm{TiB}_{2}$ powders

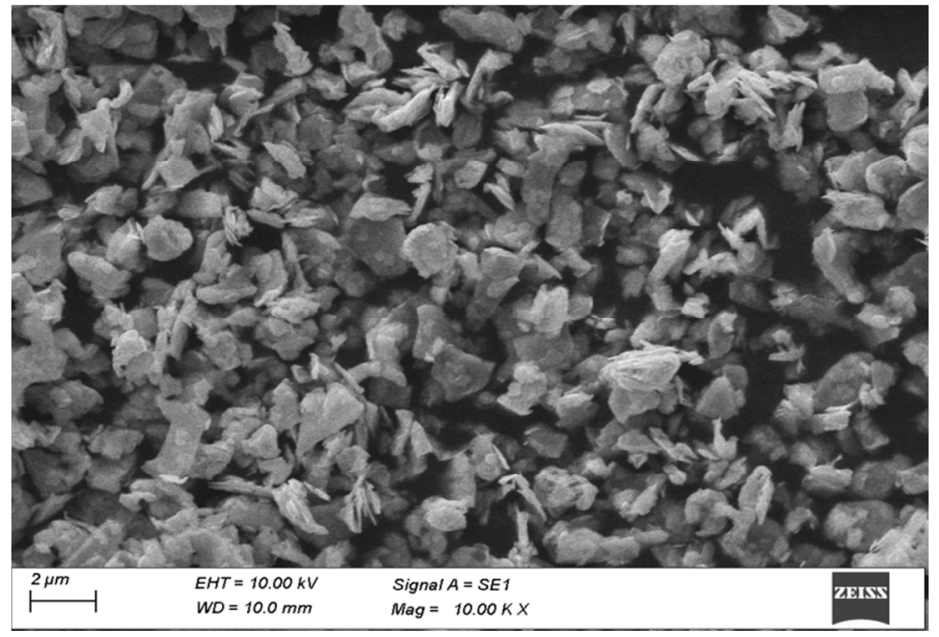

Fig. $3 \mathrm{MoS}_{2}$ powders

\subsection{Testing of composites}

The density of the unreinforced specimens and reinforced specimens was calculated by employing the Archimedes principle with the help of digital electronic weighing equipment, which has an accuracy of $0.0001 \mathrm{mg}$. The microhardness test was done on each reinforced AL7075 composite specimen and unreinforced AL7075 specimen with a $0.5 \mathrm{~kg}$ load for $15 \mathrm{sec}$ in a Vickers microhardness tester. An AISI 52100 (EN31) disc and an ASTM G99-05 fabricated composite pin were employed in the pin-on-disc equipment, which is used to study tribological properties of the unreinforced Al7075 and the reinforced Al7075 hybrid composites.

The unreinforced and the reinforced specimens were wear-tested at different parameters including the applied load of $5 \mathrm{~N}, 10 \mathrm{~N}, 15 \mathrm{~N}$ and $20 \mathrm{~N}$, the sliding distance of $200 \mathrm{~m}, 300 \mathrm{~m}$, $500 \mathrm{~m}$ and $1000 \mathrm{~m}$ and the sliding velocity of $0.5 \mathrm{~m} / \mathrm{s}, 1 \mathrm{~m} / \mathrm{s}, 1.5 \mathrm{~m} / \mathrm{s}$ and $2 \mathrm{~m} / \mathrm{s}$. The wear loss was calculated by measuring the specimen weight before and after the wear test. The coefficient of friction was calculated from the produced frictional force. The microstructure was examined before and after the wear test of specimens. 


\section{Results and discussion}

\subsection{Microstructural study}

The reinforced and unreinforced specimens were subjected to the EDX analysis to confirm the presence of elements $\left(\mathrm{Al} 17075, \mathrm{TiB}_{2}\right.$ and $\mathrm{MoS}_{2}$ ). Figs. 4 (a-e) show the presence of reinforcement elements in the fabricated composite specimen.

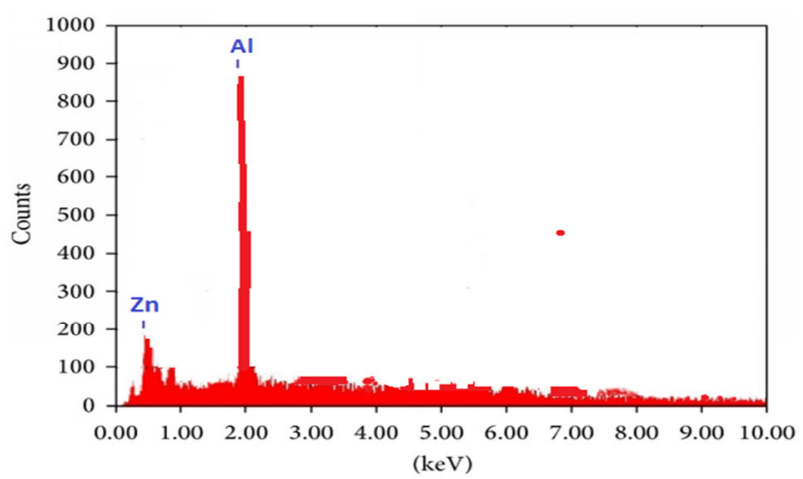

Fig. 4.a Al7075

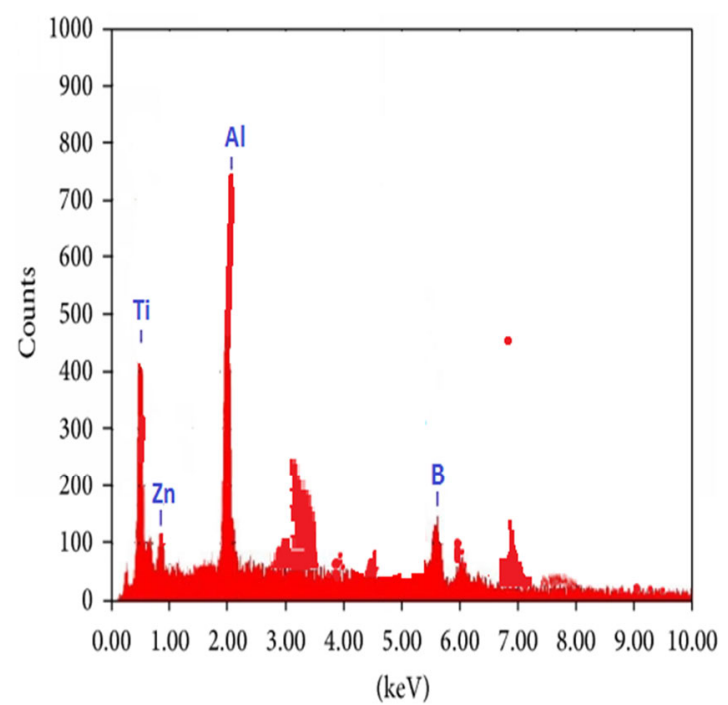

Fig. 4.b $\mathrm{Al} 7075-12 \% \mathrm{TiB}_{2}$

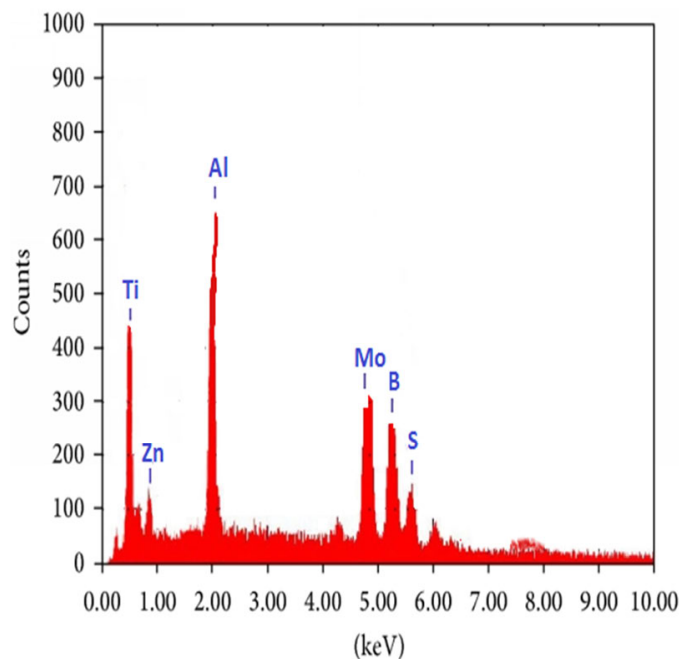

Fig. 4.d $\mathrm{Al} 7075-12 \% \mathrm{TiB}_{2} / 3 \% \mathrm{MoS}_{2}$

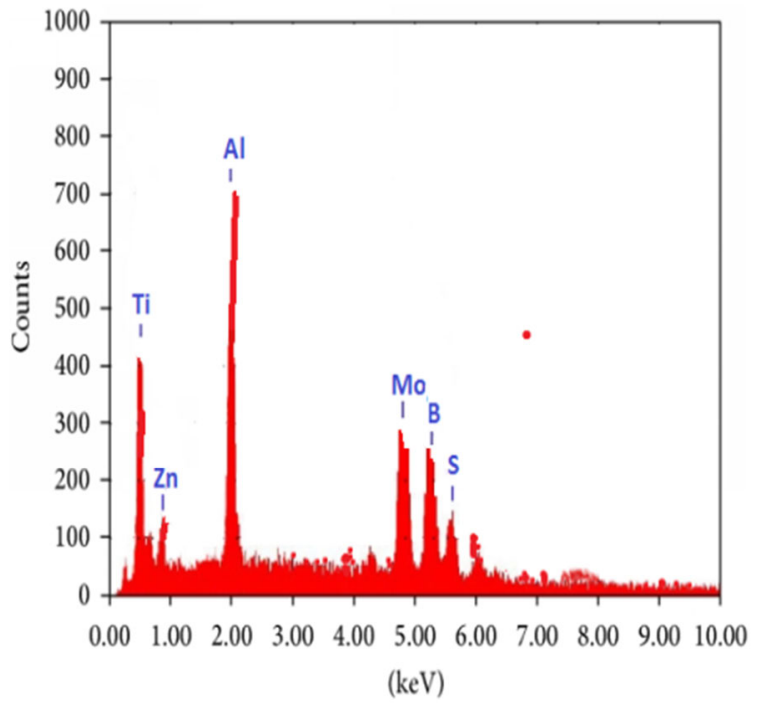

Fig. 4.c $\mathrm{Al} 7075-12 \% \mathrm{TiB}_{2}-1.5 \% \mathrm{MoS}_{2}$

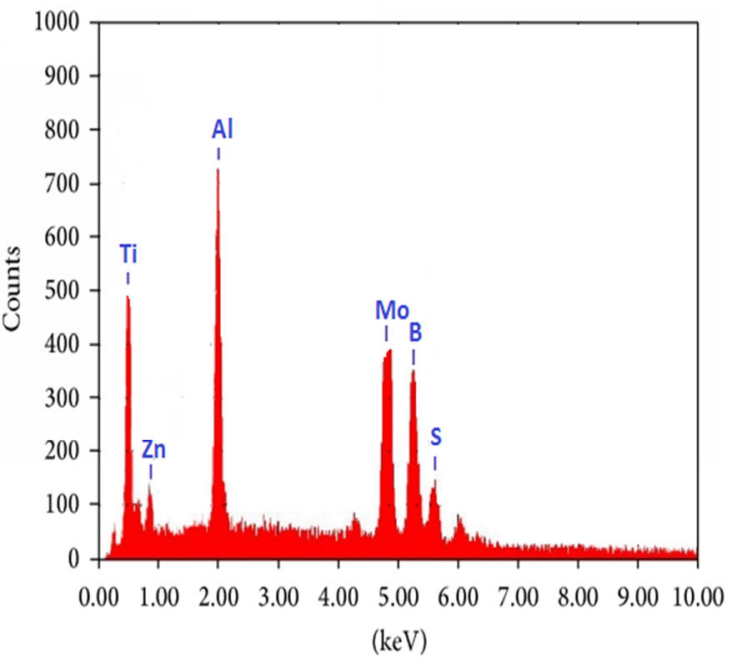

Fig. 4.e $\mathrm{Al} 7075-12 \% \mathrm{TiB}_{2}-4.5 \% \mathrm{MoS}_{2}$ 
The end of each specimen was polished with a 600, 800 and 1000 grade abrasive broads. The polished unreinforced and reinforced specimen surfaces were captured in the SEM with various scales and magnification. Fig 5.a shows the microstructure of Al7075.

Similarly, Figs. 5 (b-e) show the microstructure of the fabricated Al7075 based composites. The SEM image confirms the uniform distribution of hard and soft reinforcements in the A17075 matrix material. Porosity takes place while sulphur escapes from the hybrid composite during the sintering process [18]. Oxide forms on the surface of the hybrid composite because of the plastic deformation of powder particles during the compaction process. Besides, oxide forms due to the conversion of $\mathrm{MoS}_{2}$ into $\mathrm{MoO}_{3}$ during cooling in humid atmospheric conditions [19].

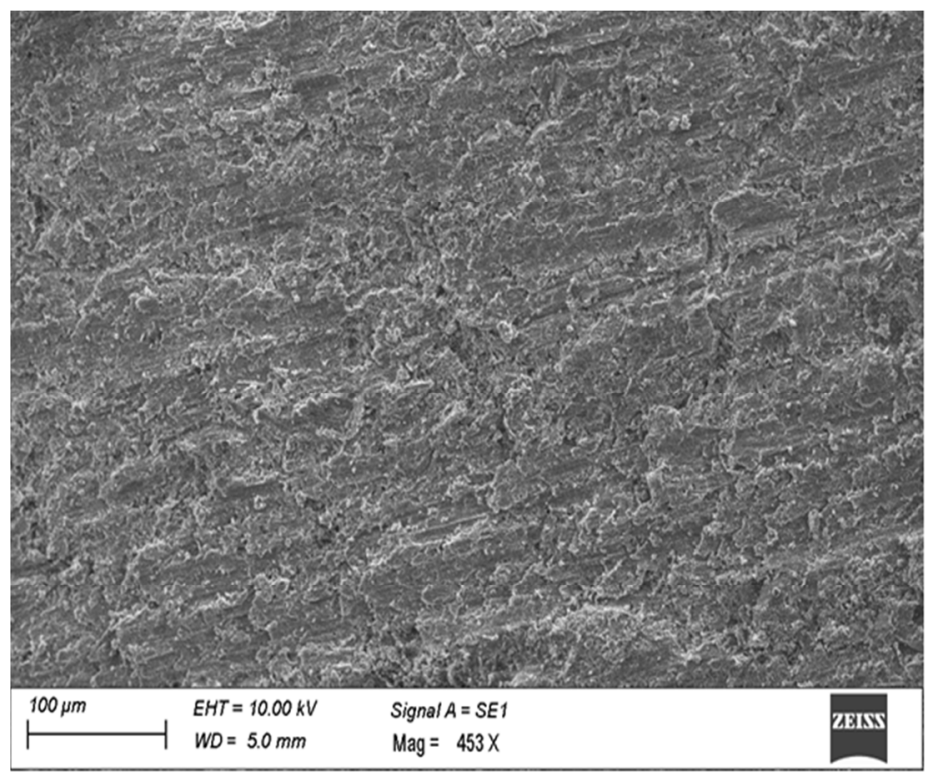

Fig. 5.a Al7075

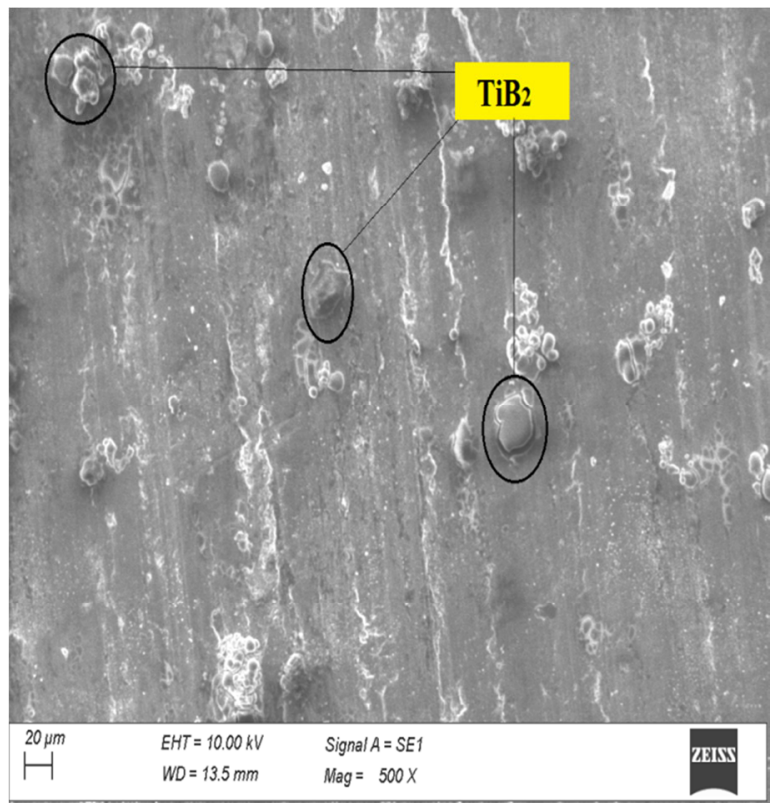

Fig. 5.b $\mathrm{Al} 7075-12 \% \mathrm{TiB}_{2}$

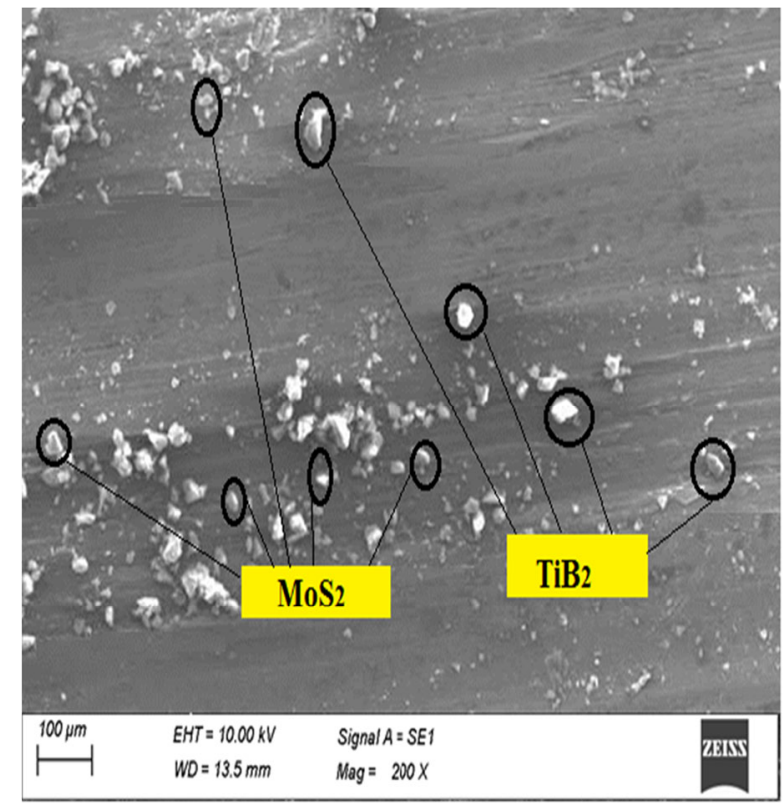

Fig. 5.c $\mathrm{Al} 7075-12 \% \mathrm{TiB}_{2}-1.5 \mathrm{MoS}_{2}$ 


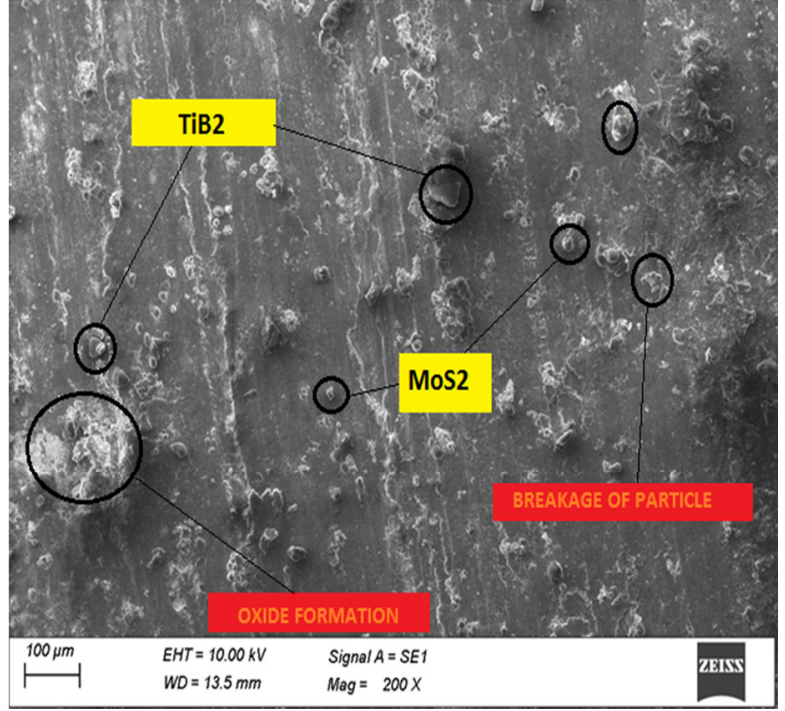

Fig. 5.d $\mathrm{Al} 7075-12 \% \mathrm{TiB}_{2}-3 \% \mathrm{MoS}_{2}$

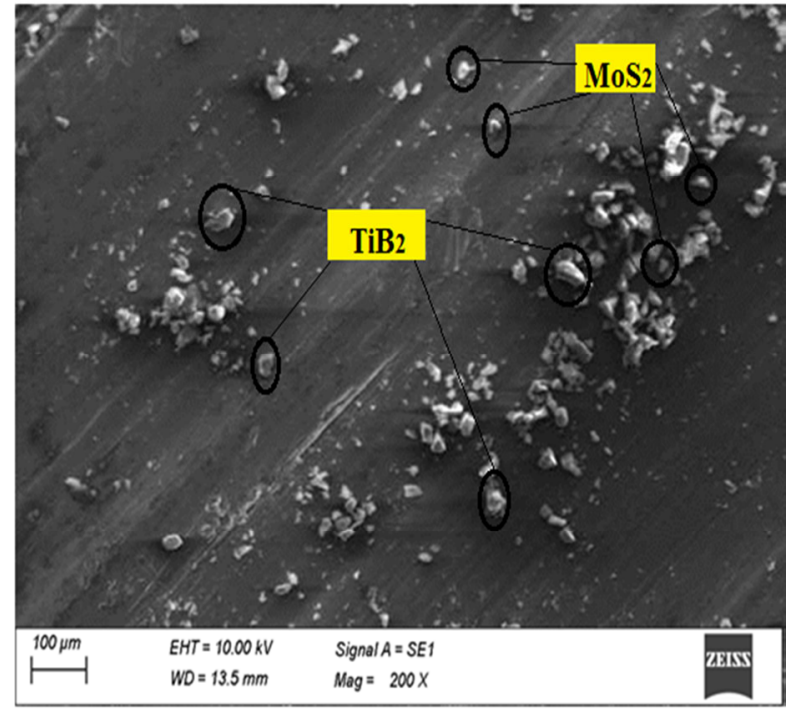

Fig. 5.e $\mathrm{A} 17075-12 \% \mathrm{TiB}_{2}-4.5 \% \mathrm{MoS}_{2}$

\subsection{Density and microhardness}

The A17075 based hybrid composite has a higher density than the unreinforced A17075 alloy. The $\mathrm{A} 17075-12 \% \mathrm{TiB}_{2}-4.5 \% \mathrm{MoS}_{2}$ has higher density than other fabricated composites. The density of A17075 and A17075 composites is shown in Table 2 and Fig. 6.a. The Al7075$12 \% \mathrm{TiB}_{2}-4.5 \% \mathrm{MoS}_{2}$ has higher microhardness than the unreinforced and other reinforced hybrid composite specimens, and Fig. 6.b. reveals that wt \% of the $\mathrm{MoS}_{2}$ reinforcement increases the microhardness of the specimen [20]. The increase in the microhardness of the hybrid specimen is due to the prevention of particle dislocation of hard and soft reinforcements and a better distribution of reinforcements in the matrix material $[21,22]$.

Table 2 Density and microhardness

\begin{tabular}{lcc}
\hline \multicolumn{1}{c}{ SAMPLES } & DENSITY $\mathbf{( g / \mathbf { c m } ^ { 3 } )}$ & MICROHARDNESS VALUE \\
\hline AL7075 & 2.829 & 92.4 \\
AL7075-12\%TIB & 105 \\
AL7075-12\%TiB $-1.5 \mathrm{MoS}_{2}$ & 2.845 & 109 \\
AL7075-12\%TiB $-3 \% \mathrm{MoS}_{2}$ & 2.856 & 114 \\
AL7075-12\%TiB $-4.5 \mathrm{MoS}_{2}$ & 2.873 & 119 \\
\hline
\end{tabular}

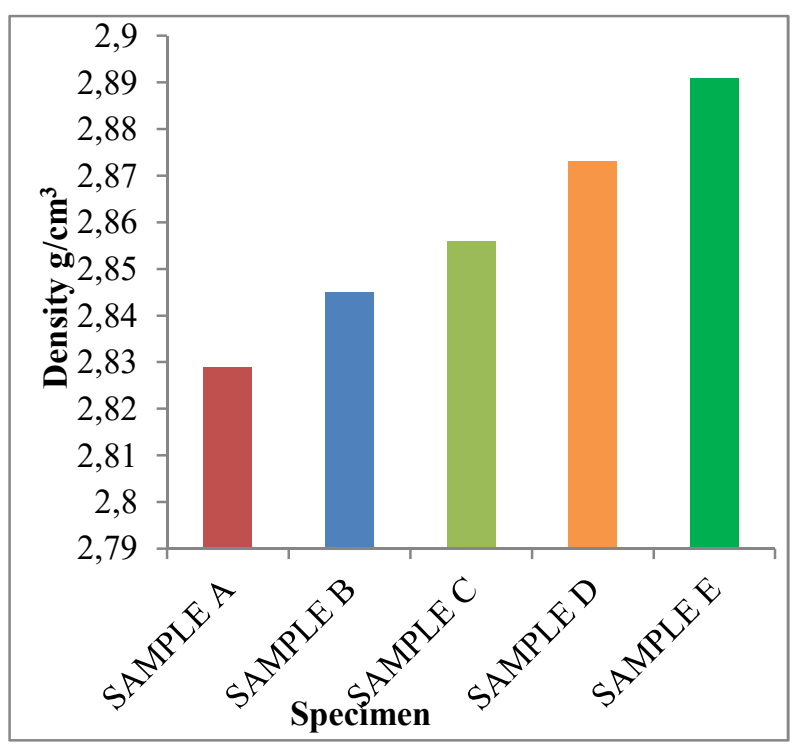

Fig. 6.a Density comparison

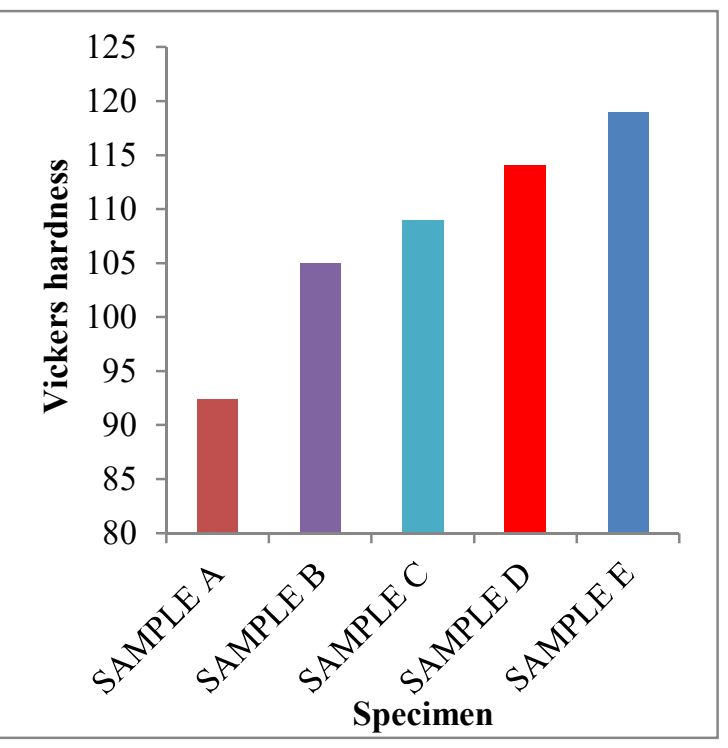

Fig. 6.b Microhardness comparison 
In Figs. 6 (a-b), sample A, sample B, sample C, sample D, sample E represent A17075,

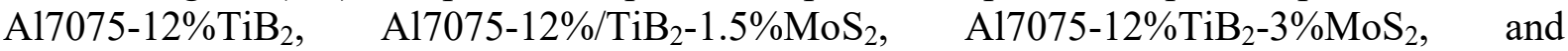
$\mathrm{Al} 707512 \% \mathrm{TiB}_{2}-4.5 \% \mathrm{MoS}_{2}$ composite specimens, respectively.

\subsection{Wear test}

The sliding wear test was conducted and tribological properties were analyzed with the help of a pin-on-disc tester. The wear tests were conducted at the applied load of $5 \mathrm{~N}, 10 \mathrm{~N}$, $15 \mathrm{~N}$ and $20 \mathrm{~N}$, the sliding velocity of $0.5 \mathrm{~m} / \mathrm{s}, 1 \mathrm{~m} / \mathrm{s}, 1.5 \mathrm{~m} / \mathrm{s}$ and $2 \mathrm{~m} / \mathrm{s}$ and the sliding distance of $200 \mathrm{~m}, 300 \mathrm{~m}, 500 \mathrm{~m}$ and $1000 \mathrm{~m}$. The wear loss and the coefficient of friction were determined for the reinforced $\mathrm{Al} 7075$ and the unreinforced Al7075 at different parameters. The AL7075-12\% $\mathrm{TiB}_{2}-4.5 \% \mathrm{MoS}_{2}$ exhibits a lower wear loss and coefficient of friction than Al7075 and any other Al7075 hybrid composites. The wear test results are shown in Tables 3-5 and Figs. 7 (a-f) for various wear test parameters. Each specimen was polished before conducting the wear test (average surface roughness $1 \mu \mathrm{m}$ ).

The wear test was conducted on all fabricated specimens with the help of pin-on-disc equipment at $0.5 \mathrm{~m} / \mathrm{s}$ sliding velocity and $1000 \mathrm{~m}$ sliding distance for every $5 \mathrm{~N}$ increase in load varying from $5 \mathrm{~N}-20 \mathrm{~N}$. The wear loss and coefficient of friction were calculated for five types of the fabricated specimens and are shown in Table. 3. Al7075-12\% $\mathrm{TiB}_{2}-4.5 \%$ $\mathrm{MoS}_{2}$ produces a minimum wear loss of $12.1 \mathrm{mg}$ and coefficient of friction of 0.131 for wear test parameters of $1000 \mathrm{~m}$ sliding distance, $0.5 \mathrm{~m} / \mathrm{s}$ sliding velocity and $5 \mathrm{~N}$ applied load. Fig. 7.a shows the behaviour of the specimen in terms of the applied load and wear loss. Fig. 7.a reveals that the wear loss increases with an increase in the applied load. Fig. 7.b shows the variation of the coefficient of friction with respect to the applied loads. Fig. 7.b reveals that the coefficient of friction (COF) increases with an increase in the applied load.

Table 3 Test conditions at sliding velocity of $0.5 \mathrm{~m} / \mathrm{s}$ and sliding distance of $1000 \mathrm{~m}$

\begin{tabular}{ccccccccccccc}
\hline & $\begin{array}{c}\text { APPLIED } \\
\text { S.NO }\end{array}$ & \multicolumn{2}{c}{ SAMD } & SAMPL A & \multicolumn{3}{c}{ SAMPLE B } & \multicolumn{3}{c}{ SAMPLE C } & \multicolumn{3}{c}{ SAMPLE D } & \multicolumn{2}{c}{ SAMPLE E } \\
\cline { 2 - 13 } & $(\mathbf{N})$ & $\begin{array}{c}\text { WL } \\
(\mathrm{mg})\end{array}$ & $\begin{array}{c}\text { COF } \\
(\mu)\end{array}$ & $\begin{array}{c}\text { WL } \\
(\mathrm{mg})\end{array}$ & $\begin{array}{c}\text { COF } \\
(\mu)\end{array}$ & $\begin{array}{c}\text { WL } \\
(\mathrm{mg})\end{array}$ & $\begin{array}{c}\text { COF } \\
(\mu)\end{array}$ & $\begin{array}{c}\text { WL } \\
(\mathrm{mg})\end{array}$ & $\begin{array}{c}\text { COF } \\
(\mu)\end{array}$ & $\begin{array}{c}\text { WL } \\
(\mathrm{mg})\end{array}$ & $\begin{array}{c}\text { COF } \\
(\mu)\end{array}$ \\
$\mathbf{1}$ & 5 & 16.9 & 0.182 & 14.9 & 0.167 & 13.5 & 0.149 & 12.8 & 0.139 & 12.1 & 0.131 \\
$\mathbf{2}$ & 10 & 18.7 & 0.194 & 16.1 & 0.179 & 14.7 & 0.164 & 13.9 & 0.155 & 12.9 & 0.147 \\
$\mathbf{3}$ & 15 & 20.2 & 0.206 & 17.6 & 0.193 & 15.9 & 0.171 & 14.6 & 0.162 & 13.5 & 0.154 \\
$\mathbf{4}$ & 20 & 22.1 & 0.219 & 18.9 & 0.201 & 17.1 & 0.182 & 15.8 & 0.173 & 14.6 & 0.166 \\
\hline
\end{tabular}

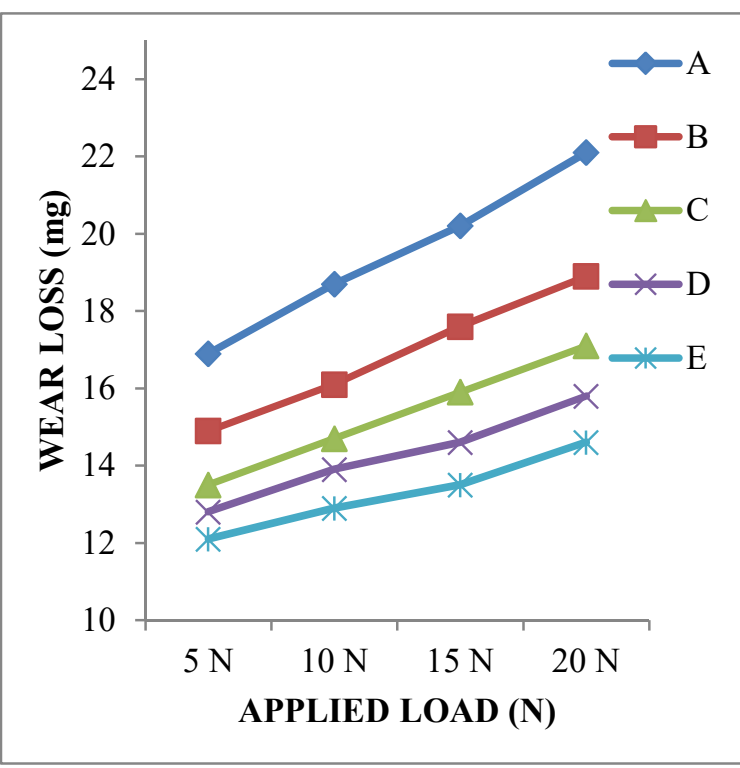

Fig. 7.a Applied load vs wear loss

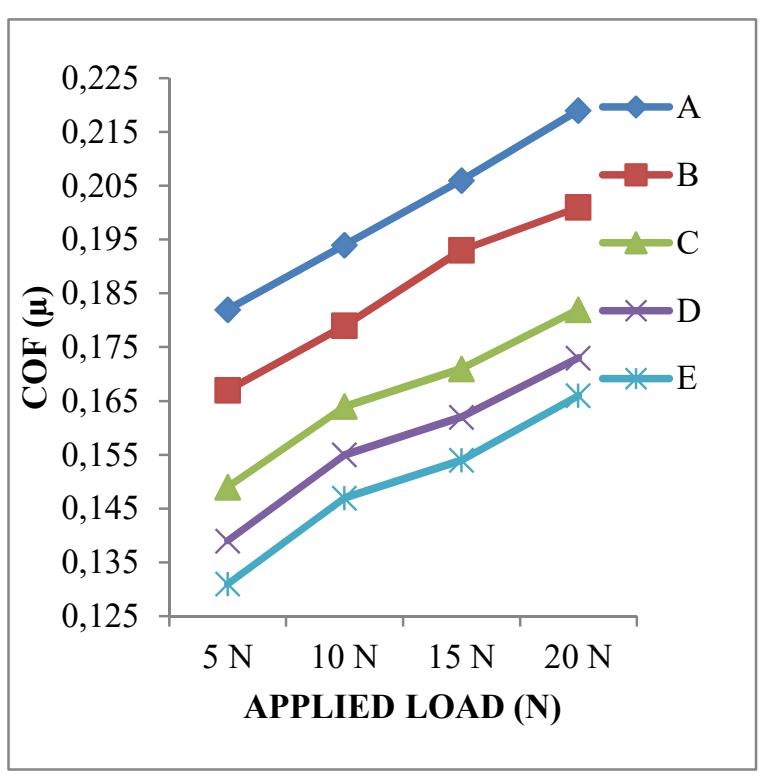

Fig. 7.b Applied load vs COF 
The coefficient of friction and wear loss results are shown in Table. 4 for the constant $1000 \mathrm{~m}$ sliding distance and the $5 \mathrm{~N}$ applied load for every $0.5 \mathrm{~m} / \mathrm{s}$ increase in the sliding velocity varying from $0.5 \mathrm{~m} / \mathrm{s}$ to $2 \mathrm{~m} / \mathrm{s}$. The minimum coefficient of friction of 0.109 and the $10.0 \mathrm{mg}$ wear loss were produced at $2 \mathrm{~m} / \mathrm{s}$ sliding velocity, $1000 \mathrm{~m}$ sliding distance and $5 \mathrm{~N}$ applied load on the A17075-12\% $\mathrm{TiB}_{2}-4.5 \% \mathrm{MoS}_{2}$ hybrid composite.

Fig. 7.c shows the behaviour of the specimens with respect to wear loss and sliding velocity. The wear loss decreases with an increase in the sliding velocity. Fig. 7.d shows the relationship between the coefficient of friction and the sliding velocity. The coefficient of friction (COF) decreases with an increase in the sliding velocity, which is shown in Fig. 7.d.

Table 4 Test conditions at applied load of $5 \mathrm{~N}$ and sliding distance of $1000 \mathrm{~m}$

\begin{tabular}{|c|c|c|c|c|c|c|c|c|c|c|c|}
\hline \multirow[b]{2}{*}{ S.NO } & \multirow{2}{*}{$\begin{array}{l}\text { SLIDING } \\
\text { VELOCITY } \\
(\mathbf{m} / \mathbf{s})\end{array}$} & \multicolumn{2}{|c|}{ SAMPLE A } & \multicolumn{2}{|c|}{ SAMPLE B } & \multicolumn{2}{|c|}{ SAMPLE C } & \multicolumn{2}{|c|}{ SAMPLE D } & \multicolumn{2}{|c|}{ SAMPLE E } \\
\hline & & $\begin{array}{c}\text { WL } \\
(\mathrm{mg})\end{array}$ & $\begin{array}{c}\mathrm{COF} \\
(\mu)\end{array}$ & $\begin{array}{c}\text { WL } \\
(\mathrm{mg})\end{array}$ & $\begin{array}{c}\mathrm{COF} \\
(\mu)\end{array}$ & $\begin{array}{c}\text { WL } \\
(\mathrm{mg})\end{array}$ & $\begin{array}{c}\mathrm{COF} \\
(\mu)\end{array}$ & $\begin{array}{c}\text { WL } \\
(\mathrm{mg})\end{array}$ & $\begin{array}{c}\mathrm{COF} \\
(\mu)\end{array}$ & $\begin{array}{c}\text { WL } \\
(\mathrm{mg})\end{array}$ & $\begin{array}{c}\mathrm{COF} \\
(\mu)\end{array}$ \\
\hline 1 & 0.5 & 16.9 & 0.182 & 14.9 & 0.167 & 13.5 & 0.149 & 12.8 & 0.139 & 12.1 & 0.131 \\
\hline 2 & 1 & 15.7 & 0.169 & 13.8 & 0.152 & 12.9 & 0.139 & 11.9 & 0.131 & 11.6 & 0.126 \\
\hline 3 & 1.5 & 14.6 & 0.156 & 12.7 & 0.141 & 11.9 & 0.131 & 11.2 & 0.123 & 10.9 & 0.120 \\
\hline 4 & 2 & 13.2 & 0.143 & 11.8 & 0.129 & 11.1 & 0.119 & 10.6 & 0.114 & 10.0 & 0.109 \\
\hline
\end{tabular}

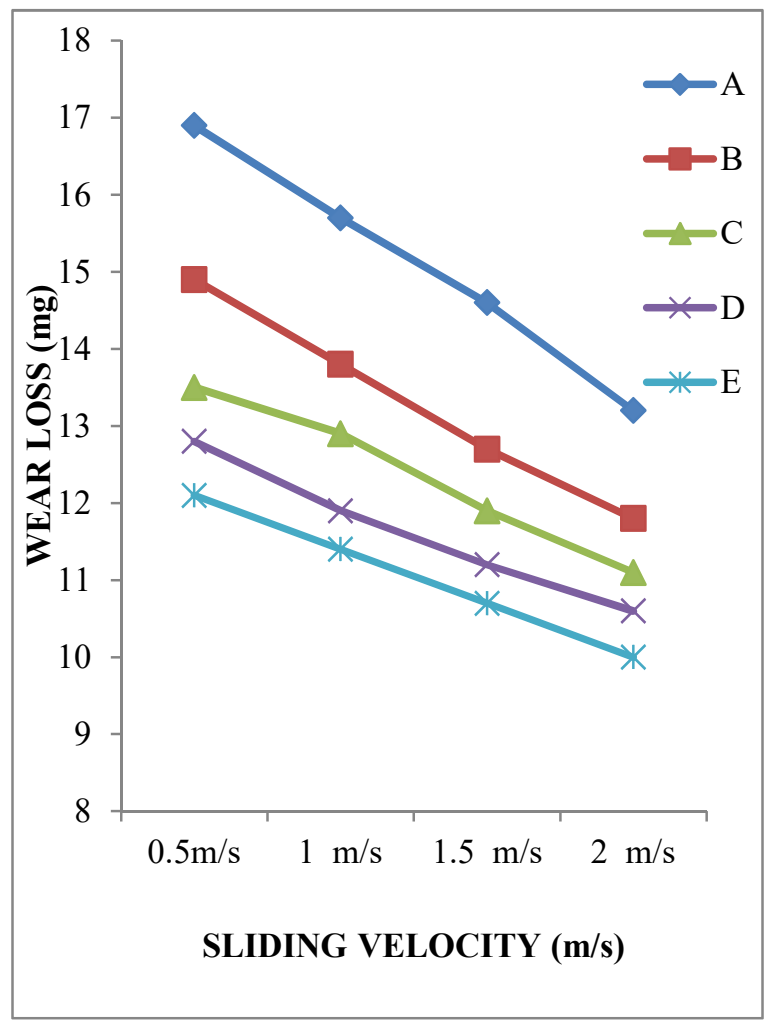

Fig. 7.c Sliding velocity vs wear loss

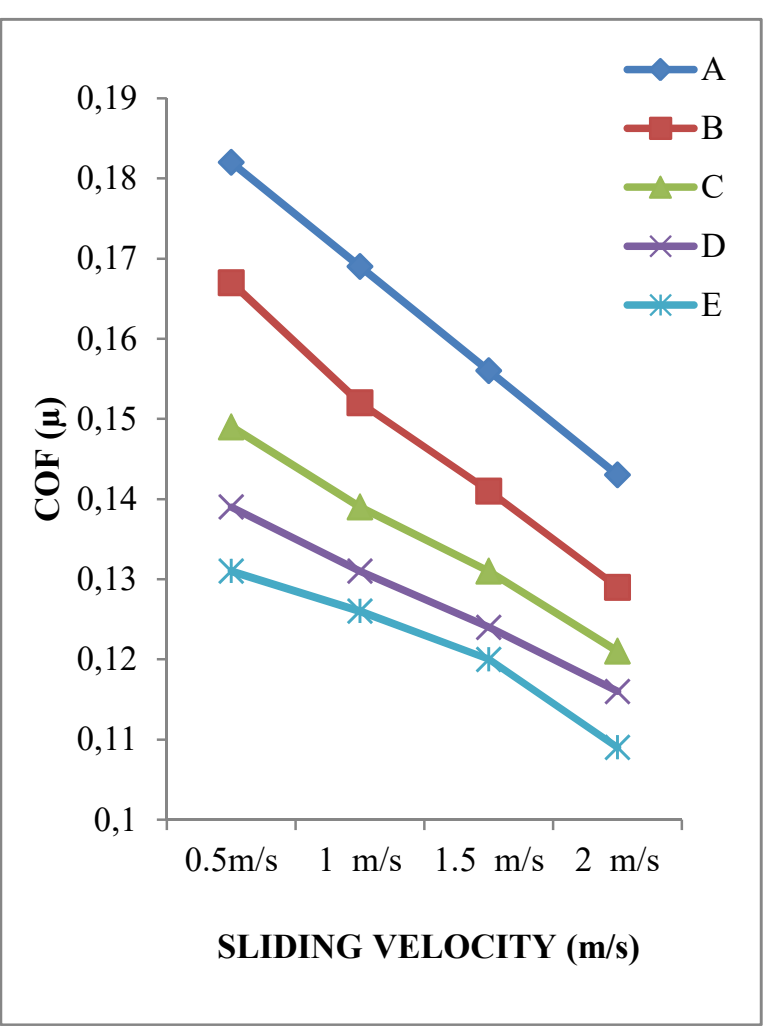

Fig. 7.d Sliding velocity vs COF

Table 5 shows the results relating to wear loss and coefficient of friction for the constantly applied load of $5 \mathrm{~N}$ and the sliding velocity of $0.5 \mathrm{~m} / \mathrm{s}$ at every sliding distance of $200 \mathrm{~m}, 300 \mathrm{~m}, 500 \mathrm{~m}$ and $1000 \mathrm{~m}$. The minimum coefficient of friction of 0.110 and the $10.4 \mathrm{mg}$ wear loss occurred in $\mathrm{Al} 7075-12 \% \mathrm{TiB}_{2}-4.5 \% \mathrm{MoS}_{2}$ in the case of the $200 \mathrm{~m}$ sliding distance, $5 \mathrm{~N}$ applied load and $0.5 \mathrm{~m} / \mathrm{s}$ sliding velocity. Fig. 7.e shows the variation of wear loss for an increased sliding distance and it is shown that wear loss increases with an increase in the sliding distance. Fig. 7.f shows the relationship between the coefficient of friction and the sliding distance. Fig. 7.f reveals that the coefficient of friction (COF) increases with an increase in the sliding distance. 
The unreinforced A17075 has high wear at the $1000 \mathrm{~m}$ sliding distance, $0.5 \mathrm{~m} / \mathrm{s}$ sliding velocity and $20 \mathrm{~N}$ applied load. The high wear loss takes place due to the continuous detachment of particles from the surface of A17075, which forms a deep narrow wear track on

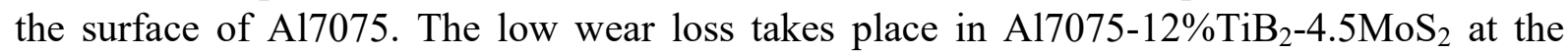
$1000 \mathrm{~m}$ sliding distance, $5 \mathrm{~N}$ applied load and $2 \mathrm{~m} / \mathrm{s}$ sliding velocity.

Table 5 Test conditions at sliding velocity of $0.5 \mathrm{~m} / \mathrm{sand}$ applied load of $5 \mathrm{~N}$

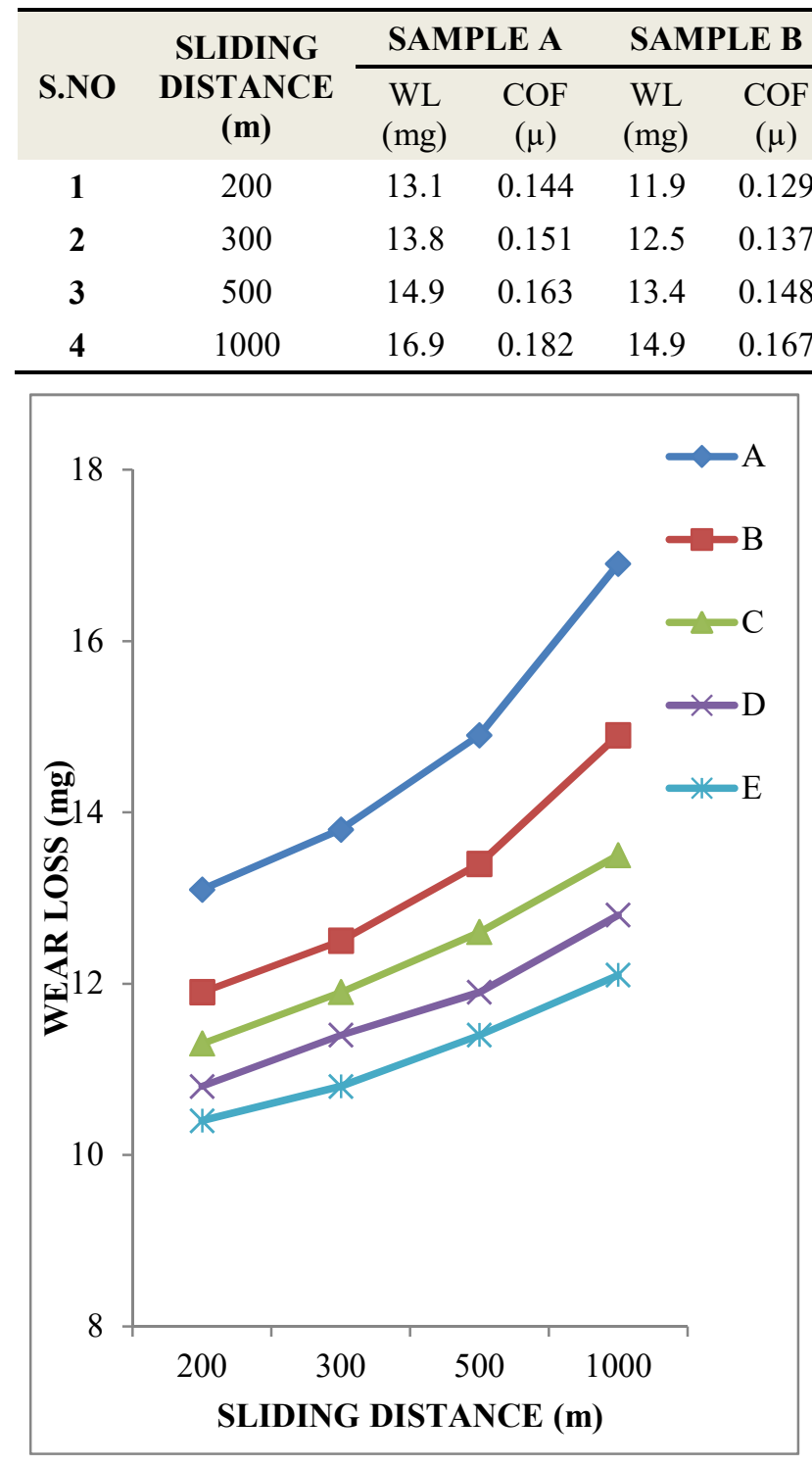

Fig. 7.e Sliding distance vs wear loss

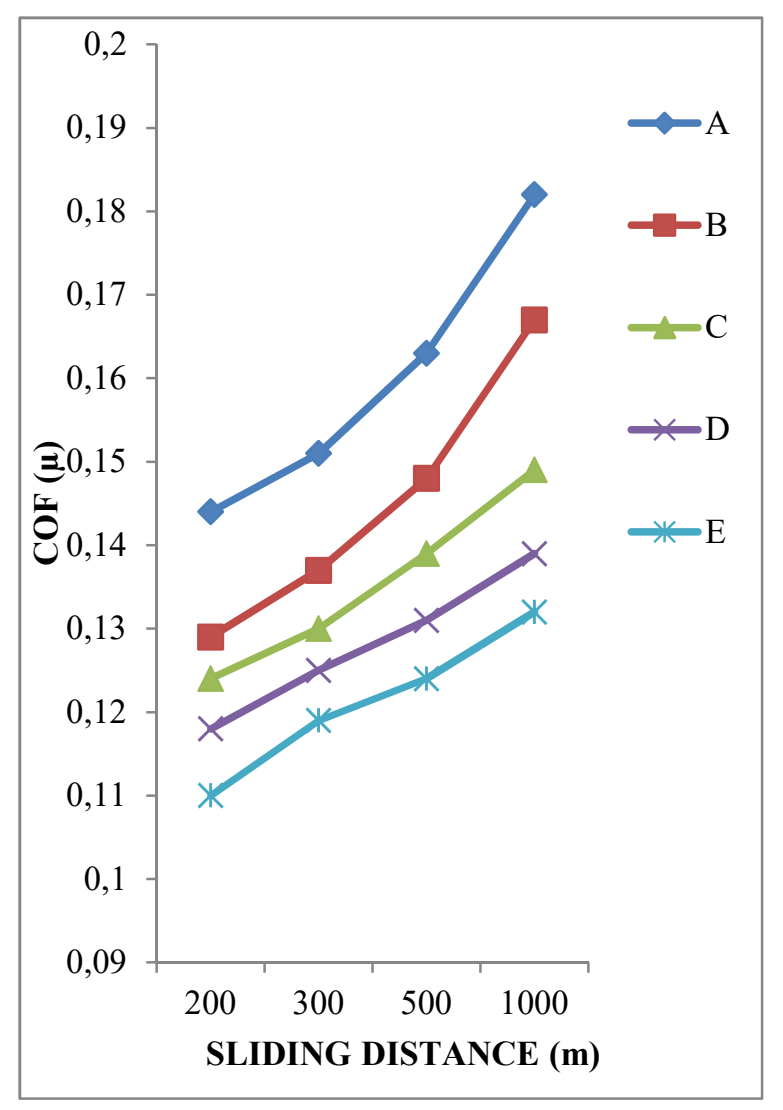

Fig. 7.f Sliding distance vs COF

In Figs. 7 (a-f)), line A, line B, line C, line D and line $\mathrm{E}$ represent A17075, Al7075-

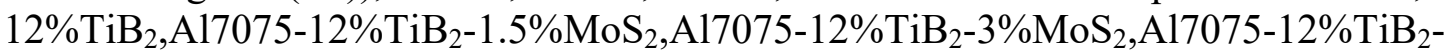
$4.5 \% \mathrm{MoS}_{2}$ composite specimens, respectively.

The worn surface of the $\mathrm{Al} 7075-12 \% \mathrm{TiB}_{2}-4.5 \mathrm{MoS}_{2}$ composite shows a lower detachment of particles due to low abrasion on the surface of the hybrid composite. An increase in the applied load increases the force required to detach the particles from the unreinforced surfaces, which leads to an increase in the depth of detached particles. The increase in the applied load on the composite specimens does not increase the depth of detached particles due to the reinforcement particles that withstand the force generated by the applied load [23]. 
The worn surface presented in the SEM image (Fig. 8.b) confirms that an increase in $\mathrm{MoS}_{2} \mathrm{wt} \%$ in every Al7075 hybrid composite decreases the surface contact by acting as a solid lubricant between the reinforced A17075 composite material pin and disc [19,24]. It leads to a reduction in the wear loss by reducing the number of detachment particles from reinforced surfaces and to a reduction in the coefficient of friction during the wear test. The increase in the sliding velocity decreases the duration of the force acting on the particles of the surfaces and increases the spreading of $\mathrm{MoS}_{2}$ in the reinforced surfaces, which leads to a decrease in the wear loss and coefficient of friction. The increase in the sliding distance increases the wear loss and coefficient of friction because of the increase in the number of particles detached from the surfaces.

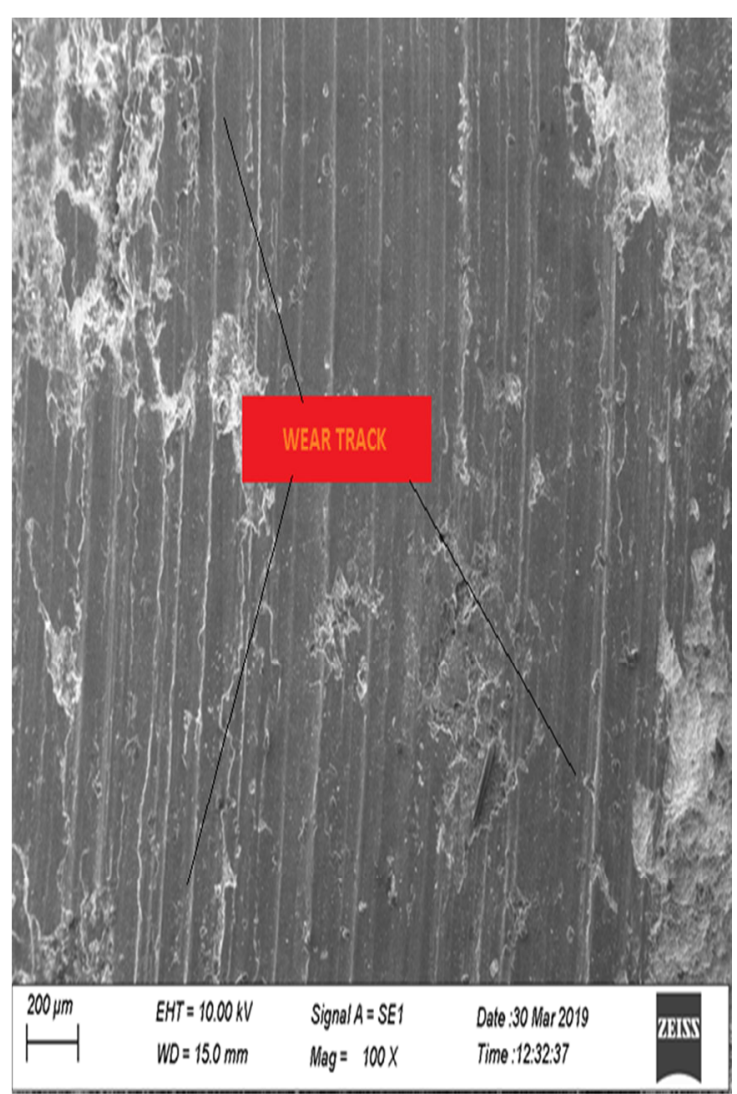

Fig. 8.a Worn surface of AL7075

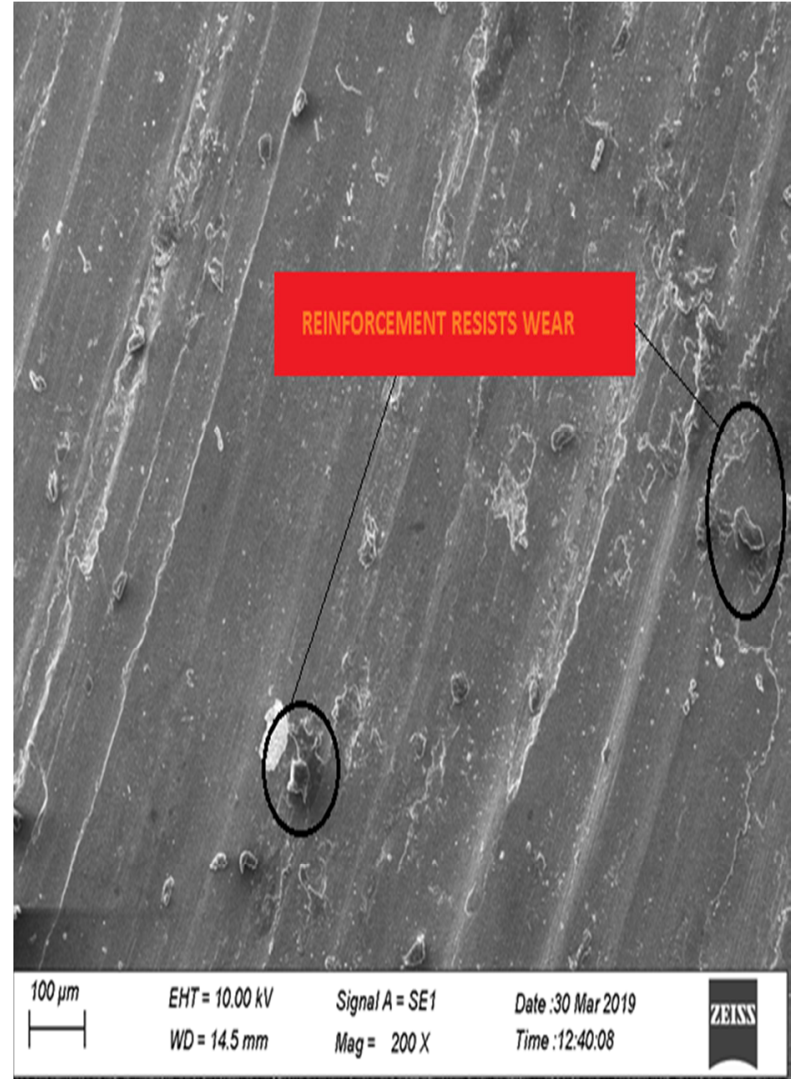

Fig. 8.b Worn surface of AL7075-12\% $\mathrm{TiB}_{2}-4.5 \% \mathrm{MoS}_{2}$

The SEM images corresponding to the lowest $10.0 \mathrm{mg}$ and highest $22.1 \mathrm{mg}$ wear loss are shown in Figs. 8 (a-b).

\section{Conclusions}

In this investigation, AL7075, AL7075-TiB, $\mathrm{Al} 7075-\mathrm{TiB}_{2}-\mathrm{MoS}_{2}$ samples were fabricated using the powder metallurgy technique. The density and microhardness of the fabricated composite increased with an increase in $\mathrm{wt} \%$ of reinforcement. $\mathrm{TiB}_{2}$ profoundly influenced the property of wear resistance, but $\mathrm{MoS}_{2}$ had more influence on providing a better coefficient of friction and wear properties. The wear test results reveal that the wear loss and the coefficient of friction increased with an increase in the applied load and sliding distance. The wear loss and coefficient of friction decreased with an increase in the sliding velocity. $\mathrm{A} 17075-12 \% \mathrm{TiB}_{2}-4.5 \% \mathrm{MoS}_{2}$ produced the minimum wear loss and coefficient of friction at the sliding velocity of $2 \mathrm{~m} / \mathrm{s}$, sliding distance of $1000 \mathrm{~m}$ and applied load of $5 \mathrm{~N}$. The optimization of composition and tribological properties of hybrid composite material will be the scope of a future investigation. 


\section{REFERENCES}

[1] Zhang, L.H Jiang, Y Fang, Q.F Zhang, T Wang, X.P and Liu, C.S. 'Toughness and microstructure of tungsten fibre net-reinforced tungsten composite produced by spark plasma sintering', Materials Science and Engineering: A, 2016, Vol. 659, pp.29-36, https://doi.org/10.1016/j.msea.2016.02.034

[2] Ravichandran, M Naveen Sait, A and Anandakrishnan,V. 'Synthesis and forming behavior of aluminiumbased hybrid powder metallurgic composites', International Journal of Minerals, Metallurgy, and Materials, 2013, Vol. 21, No. 2, pp.181-189, https://doi.org/10.1007/s12613-014-0883-z.

[3] Dinesh S, Godwin Antony A, K.Rajaguru, V.Vijayan,'Investigation and Prediction of Material Removal Rate and Surface Roughness in CNC Turning of EN24 Alloy Steel", Mechanics and Mechanical Engineering, 2016, 20 (4), 451-466, https://doi.org/10.5958/2249-7315.2016.00654.7

[4] Ravichandran, M Naveen Sait, A and Anandakrishnan,V. 'Densification and deformation studies on powder metallurgy $\mathrm{Al}_{-} \mathrm{TiO}_{2}-\mathrm{Gr}$ composite during cold upsetting', Journal of Materials Research, 2014, Vol. 29, No. 13, pp.1480-1487. https://doi.org/10.1557/jmr.2014.143

[5] Norajitra, P Boccaccini, L. V and Diegele, E 'Development of a helium-cooled divertor concept: designrelated requirements on materials and fabrication technology. Journal of Nuclear Materials, 2004, pp.1594-1598. https://doi.org/10.1016/j.jnucmat.2004.04.137

[6] Hu, S.W Zhao, Y.G Wang, Z Li, Y.G and Jiang, Q.C. 'Fabrication of in situ TiC locally reinforced manganese steel matrix composite via combustion synthesis during casting', Materials and Design, 2013, Vol. 44, pp.340-345. https://doi.org/10.1179/1879139514Y.0000000140

[7] James, W.B., High Performance Ferrous P/M Materials for Automotive Applications, Metal Powder Report, 1991, 46 [9]. https://doi.org/10.1016/0026-0657(91)90335-X

[8] Yao PP, Xiao YL, Deng JW. Study on space copper-based powder metallurgy friction material and its tribological properties. Adv Mater Res 2011; 284-286: 479-487. https://doi.org/10.4028/www.scientific.net/AMR.284-286.479

[9] Kumar, S \& Balasubramanian, V, 'Developing a mathematical model to evaluate wear rate of AA7075/SiCp powder metallurgy composites', Wear, 2008, vol.264, no 11-12, pp. 1026-1034. https://doi.org/10.1016/j.wear.2007.08.006

[10] Mishra, RS, Mahoney, MW, McFadden, S, Mara, NA \& Mukherjee, AK, 'High strain rate superplasticity in a friction stir processed 7075 Al alloy’, Scripta Materialia, 1999, vol.42, no.2, pp.163-168, https://doi.org/10.1016/S1359-6462 (99)00329-2

[11] X. Ding, L. Luo, H. Chen, G. Luo, X. Zhu, X. Zan, J. Cheng, and Y. Wu, 'Fabrication of W-1 wt.\% TiC composites by spark plasma sintering', Fusion Eng. Des. 92, 2015, pp. 29-34. https://doi.org/10.1016/j.fusengdes.2015.01.003

[12] Sekar Saravanan, Palanisamy Senthilkumar, Manickam Ravichandran, and Veeramani Anandakrishnan, 'Mechanical, electrical and corrosion behavior of AA6063/TiC composites synthesized via stir casting route', Journal Materials Research, 2017, Vol. 32, No. 3, Pp.606-614. https://doi.org/10.1557/jmr.2016.503

[13] Ravichandran, $\mathrm{M}$ and Anandakrishnan, $\mathrm{V}$. 'Optimization of $\mathrm{P} / \mathrm{M}$ parameters to attain maximum strength in Al-10 wt. \% $\mathrm{MOO}_{3}$ composite. J Mater Res, 2015, 30:2380-2387, https://doi.org/10.1557/jmr.2015.211

[14] Yahya Hıs_man Çelik, Kübra Seçilmis 'Investigation of wear behaviours of Al matrix composites reinforced with different $\mathrm{B}_{4} \mathrm{C}$ rate produced by powder metallurgy method. Advanced Powder Technology’. 2017, Volume 28, Issue 9, September 2017, Pages 2218-2224. https://doi.org/10.1016/j.apt.2017.06.002

[15] Ning Wu, Fengdan Xue, Hailin Yang, Guoping Lia, Fenghua Luo, Jianming Ruan 'Effects of TiB particle size on the microstructure and mechanical properties of $\mathrm{TiB}_{2}$-based composites' Ceramics International' 2019, 45 1370-1378. https://doi.org/10.1016/j.ceramint.2018.08.270

[16] P. Ravindranan, K. Manisekar, R. Narayanasamy, P.Narayanasamy, 'Tribological behaviour of powder metallurgyprocessedaluminium hybrid composites with the addition of graphite solid lubricant, Ceram. Int. 39, 2013, 1169-1182'. https://doi.org/10.1016/j.ceramint.2012.07.041

[17] Mohammad rouhi, Mohammad moazami goudarzi, Mohammad ardestani 'Comparison of effect of SiC and $\mathrm{MoS}_{2}$ on wear behavior of Al matrix composites 'Transactions of Nonferrous Metals Society of China', Volume, July 2019, Pages 1169-1183. https://doi.org/10.1016/S1003-6326(19)65025-9 
[18] S. DhanasekaranR, Gnanamoorthy, 'Microstructure, strength and tribological behavior of $\mathrm{Fe}-\mathrm{C}-\mathrm{Cu}-\mathrm{Ni}$ sintered steels prepared with $\mathrm{MoS}_{2}$ addition' journal of materials science, 2007, Volume 42, Issue 12, pp 4659-4666. https://doi.org/10.1007/s10853-006-0385-0

[19] Özlem Baran „, Faruk Bidev, Hikmet Çiçek, Levent Kara 'Investigation of the friction and wear properties of $\mathrm{Ti} / \mathrm{TiB}_{2} / \mathrm{MoS}_{2}$ graded-composite coatings deposited by CFUBMS under air and vacuum conditions' Surface \& Coatings Technology', 2014. https://doi.org/10.1016/j.surfcoat.2014.07.033

[20] J. S. David Joseph, B. Kumaragurubaran, S. Sathish, 'Effect of $\mathrm{MoS}_{2}$ on the Wear Behavior of Aluminium (AlMg0.5Si) Composite' Silicon, 2019, volume 11. https://doi.org/10.1007/s12633-019-00238-x

[21] Zhang X, Dong P, Zhang B, Tang S, Yang Z, Chen Y, et al.' Preparation and characterization of reduced graphene oxide/copper composites incorporated with nano- $\mathrm{SiO}_{2}$ particles' Alloys Compound, 2016, 671:465-72. https://doi.org/10.1016/j.jallcom.2016.02.068

[22] Shafiei-Zarghani*, S.F. Kashani-Bozorg, A. Zarei-Hanzaki, 'Abrasive wear Behaviour of $\mathrm{TiB}_{2}$ Fabricated Aluminum 6061'Mat. Science and Engineering A 500 2009, 84-91, https://doi.org/10.1016/j.matpr.2017.11.082

[23] H.B. MichaelRajan S.Ramabalan I.Dinaharan S.J.Vijay 'Effect of $\mathrm{TiB}_{2}$ content and temperature on sliding wear behaviorof AA7075/ $\mathrm{TiB}_{2}$ in situ aluminum cast composites' Achieves of civil and mechanical engineering, 2014, 14 (1) 72 - 79, https://doi.org/10.1016/j.acme.2013.05.005

[24] A.Baradeswaran, A.Elaya Perumal, 'Study on mechanical and wear properties of $\mathrm{Al} 7075 / \mathrm{Al}_{2} \mathrm{O}_{3} /$ graphite hybrid composites' Composites Part B Engineering, January 2014, Volume 56, Pages 464-471, https://doi.org/10.1016/j.compositesb.2013.08.013

Submitted: $\quad 20.12 .2019$

Accepted: $\quad 10.02 .2020$
Ashok Raj.R

Assistant professor,

Mechanical engineering,

J J College of Engineering and

Technology, Trichy-620009, India ashok_noveltyguy@yahoo.com Dr.R.Pavendhan

Professor, Mechanical engineering, Er.Perumal Manimekalai college of Engineering, Hosur - 635117, India mr_paventhan@yahoo.com

Dr.B.Kumaragurubaran Assistant Professor(Sr.Gr), Mechanical Engineering, University college of Engineering, BIT Campus, Anna University, Trichy-620024, India guru17381@gmail.com 